University of Nebraska - Lincoln

DigitalCommons@University of Nebraska - Lincoln

Faculty Papers and Publications in Animal

Science

Animal Science Department

1967

\title{
Plant vs. Animal Protein as a Source of Supplemental Protein for the Gilt
}

Dwane R. Zimmerman

University of Nebraska-Lincoln

E. R. Peo, Jr.

University of Nebraska-Lincoln

D. B. Hudman

Texas A \& M University

Follow this and additional works at: https://digitalcommons.unl.edu/animalscifacpub

Part of the Animal Sciences Commons

Zimmerman, Dwane R.; Peo, Jr., E. R.; and Hudman, D. B., "Plant vs. Animal Protein as a Source of Supplemental Protein for the Gilt" (1967). Faculty Papers and Publications in Animal Science. 629. https://digitalcommons.unl.edu/animalscifacpub/629

This Article is brought to you for free and open access by the Animal Science Department at DigitalCommons@University of Nebraska - Lincoln. It has been accepted for inclusion in Faculty Papers and Publications in Animal Science by an authorized administrator of DigitalCommons@University of Nebraska - Lincoln. 


\title{
PLANT VS. ANIMAL PROTEIN AS A SOURCE OF SUPPLEMENTAL PROTEIN FOR THE GILT ${ }^{1}$
}

\author{
Dwane R. Zimmerman, E. R. Peo, Jr. And D. B. Hudman ${ }^{2}$ \\ Nebraska Agriculture Experiment Station, ${ }^{3}$ Lincoln
}

$\mathrm{P}_{\mathrm{b}}$ ROTEIN of animal origin has frequently been suggested to have greater nutritional value for swine reproduction than protein of plant origin. Moustgaard (1952) reported that gilts fed a diet in which the supplemental protein was of animal origin (soured separated milk) reached puberty earlier and had a greater ovulation rate and greater embryo survival and litter size at 26 to 29 days of gestation than gilts fed a diet in which the supplemental animal protein was replaced with protein of plant origin. Most of the advantage of the animal protein diet was eliminated when the all-plant diet was supplemented with vitamin $\mathbf{B}_{12}$. Fowler and Robertson (1954) reported similar advantages in age at puberty, ovulation rate and litter size from replacing $50 \%$ of the supplemental plant protein with protein of animal origin. These differences were markedly reduced when an antibiotic-vitamin $\mathbf{B}_{12}$ supplement was added to the all-plant diet.

The results reported since the present investigation was initiated (Teague and Rutledge, 1960; Clawson and Barrick, 1959; Mayrose et al., 1964) indicate little if any beneficial effect on reproductive performance from replacing part or all of the supplemental protein in adequately fortified all-plant diets with protein of animal origin.

The purpose of the present experiment was to determine the value for swine reproduction of replacing part of the supplemental protein in an adequately fortified all-plant diet (cornsoybean meal) with protein of animal origin (meat and bone scraps).

\section{Materials and Methods}

Preliminary Observations. Thirty-four gilts in a growing-finishing experiment conducted in 1959 (Peo and Hudman, 1962) were

\footnotetext{
1 Published with the approval of the director of the Nebraska Agriculture Experiment Station as Paper No. 1966, Journal Series.

2 Present address: Department of Animal Science, Agriculture Extension Service, Texas A \& M University, College Station.

${ }_{3}^{3}$ Department of Animal Science, University of Nebaska, Lincoln. Acknowledgement is made to $\mathrm{P}$. F. Cunningham et al. for assistance in caring for the animals.
}

checked daily for estrus with a vasectomized boar. A basal corn-soybean meal diet was compared to diets in which meat and bone scraps were substituted for soybean meal and composed 2.5, 5.0, 7.5 or $10.0 \%$ of the diet. Daily heat checks were initiated when the first born gilt was 150 days of age and continued until all gilts were slaughtered following completion of the finishing test. Gilts that reached puberty before the assigned slaughter date were maintained on the experimental diets until after they had exhibited a second estrus. At slaughter, gross examination was made of the ovaries for signs of ovulation and of the complete reproductive tract for abnormalities. A count was made of the corpora lutea present on the ovaries of gilts that had cycled prior to slaughter.

Main Experiment. Fifty-four crossbred gilts (Hampshire--Yorkshire) from 18 litters were allotted to three replications of three dietary treatments on the basis of litter and weight. Litters were assigned to replicate on the basis of the average weight of the three gilts selected at random from each litter. The littermate gilts in each weight-replicate group were then assigned at random to the diets outlined in table 1 . Replicates were assigned at random to three blocks of pens and diets to the three pens in each block.

The gilts averaged 8 weeks of age ( 7 to 9 week range) and $19.4 \mathrm{~kg}$. liveweight at the start of the experiment on May 4, 1960. The average initial weights were $22.8,19.0$ and $16.9 \mathrm{~kg}$. for the heavy (I), medium (II), and light (III) replicates and 19.3, 19.7 and 19.3 $\mathrm{kg}$. for diets A, B and C, respectively.

The basal diet (A), an all-plant protein, corn-soybean meal diet, was compared with diets in which meat and bone scraps were substituted for approximately $35 \%$ or $70 \%$ of the soybean meal and made up either $5 \%$ (diet B) or $10 \%$ (diet C) of the total diet. The meat and bone scraps used were prepared by blending four commercial sources. The additions of trace minerals, antibiotics and vitamins were similar for all diets (table 1 ). The vitamin $A, D_{2}, B_{2}$ and $B_{12}$ additions were 
TABLE 1. COMPOSITION OF EXPERIMENTAL DIETS $^{\text {a }}$

\begin{tabular}{|c|c|c|c|}
\hline \multirow[b]{2}{*}{ Ingredients } & \multicolumn{3}{|c|}{$\operatorname{Diet}^{\mathbf{b}}$} \\
\hline & $\begin{array}{c}\text { A } \\
\text { C-SB }\end{array}$ & $\begin{array}{c}\text { B } \\
5 \% \\
\text { MBS }\end{array}$ & $\begin{array}{c}C \\
10 \% \\
\text { MBS }\end{array}$ \\
\hline & $\%$ & $\%$ & $\%$ \\
\hline Ground yellow corn & 82.5 & 83.7 & 84.3 \\
\hline Soybean meal, $50 \%$ & 14.3 & 9.1 & 4.0 \\
\hline $\begin{array}{l}\text { Meat and bone scraps, } \\
50 \%\end{array}$ & & 5.0 & 10.0 \\
\hline Salt (iodized) & 0.5 & 0.5 & 0.5 \\
\hline Dicalcium phosphate & 0.6 & & \\
\hline Ground limestone & 1.0 & 0.6 & 0.1 \\
\hline Trace minerals ${ }^{\mathrm{d}}$ & 0.1 & 0.1 & 0.1 \\
\hline $\begin{array}{l}\text { Vitamin-antibiotic } \\
\text { premix }^{e}\end{array}$ & 1.0 & 1.0 & 1.0 \\
\hline
\end{tabular}

a Calculated content of protein in all diets $14 \%$; calcium and phosphorus levels were .57 and $.40 \%$ in diet $A$. The calcium:phosphorus ratio was held approximately constant $(1.42: 1)$ for all diets, but it was not possible to maintain the same levels of calcium and phosphorus in the diets.

b $\mathrm{C}-\mathrm{SB}$, corn soybean meal basal; MBS, meat and bone craps.

Blend of four commercial sources.

a Calcium Carbonate Co., Quincy, Ill. Composition (\%): $\mathrm{Mn}, 10.0 ; \mathrm{Fe}, 10.0 ; \mathrm{Cu}, 1.0 ; \mathrm{Co}, 0.10 ; \mathrm{I}, 0.30 ; \mathrm{Zn}, 5.0$ and $\mathrm{Ca}, 11.75$

Contributed the following amounts of vitamins and antibiotics per kg. of complete diet: vitamin A 2640 I.U.; vitamin $\mathrm{D}_{2}, 306$ I.U.; riboflavin $2.2 \mathrm{mg}$; niacin $9.9 \mathrm{mg}$; calcium pantothenate, $4.4 \mathrm{mg}$; choline chloride, $231 \mathrm{mg}$.; vitamin $\mathrm{B}_{12}$, $11.0 \mathrm{mcg}$; oxytetracycline, $22 \mathrm{mg}$.

adequate to meet the N.R.C. daily requirements for finishing swine (N.R.C. Publication $648,1959)$. The Ca:P ratio was similar for all diets.

The pigs were housed and group-fed in concrete-floored pens equipped with selffeeders and automatic waterers during the complete experiment. Individual weights and the feed consumption per pen were determined at 2 -week intervals during the experiment.

Daily heat checks with vasectomized boars were begun when the first born litter in the experiment was 150 days of age. The heat checks were continued until the gilts were slaughtered after mating or until approximately $10 \mathrm{mo}$. of age if a puberal heat was not observed.

The gilts were mated at random to four yearling Hampshire boars. Each gilt was allowed one service on the first day of the second heat period. The boars had all sired a previous pig crop and had good conception and littering records. The intention was to use three boars. However, one of the boars was injured after mating seven gilts and a littermate boar was substituted for the remainder of his assigned matings.

The gilts were slaughtered at 26 to 28 days of gestation. The reproductive tracts were examined for gross abnormalities and a count was made of corpora lutea on the ovaries. The contents of each uterine horn were removed and the numbers and condition of the embryos determined. An embryo was considered live if its heart beat was visible or if there was no gross evidence of tissue degeneration. Embryo survival is defined in this study as the percent of the corpora lutea represented by live embryos at slaughter. It is recognized that losses in addition to embryonic mortality (e.g., lack of fertilization) are included.

Some gilts contributed only partial data to the experiment. Three gilts that returned to heat after breeding were slaughtered when they were first observed in estrus, so that ovulation rate could be determined at the "mating" estrus by counting the number of regressing corpora lutea on the ovaries. Since no gross abnormalities were visible, their embryo survival was considered as $0 \%$. Three gilts were not observed in heat by approximately $10 \mathrm{mo}$. of age and were slaughtered. For purposes of statistical analysis, puberty was considered to have occurred on the day of slaughter. Statements of statistical significance are based on a probability level of $5 \%$ or less.

\section{Results and Discussion}

Preliminary Observations. Only $47 \%$ of the 34 gilts studied in the preliminary experiment exhibited estrus prior to slaughter. For diets containing $0,2.5,5,7.5$ and $10 \%$ meat and bone scraps, respectively, the number of gilts on each dietary treatment was 7, 8, 6, 5 and 8 ; the percent in estrus before slaughter was $71,38,33,60$ and 38 ; the average age at puberty (days) was 193, 195, 185, 193 and 211 ; the number of second-heat corpora lutea was 14, 13, 13.5, 12 and 12.7. These data did not reveal any improvement in reproductive performance from replacing up to $70 \%$ of the soybean meal in the diet with meat and bone scraps. Because of the limited nature of these observations and the fact that they were not in complete agreement with data reported previously (Moustgaard, 1952; Fowler and Robertson, 1954), the main experiment was conducted.

Main Experiment. The gain and puberty data are presented in table 2. Gilts fed the corn-soybean meal and the $5 \%$ meat and bone scrap diets (A and B) gained similarly, but at a faster rate than gilts fed the $10 \%$ meat and 
TABLE 2. WEIGHT GAIN AND AGE AT PUBERTY AS INFLUENCED BY TWO LEVELS OF MEAT AND BONE SCRAPS

\begin{tabular}{|c|c|c|c|}
\hline \multirow[b]{2}{*}{ Item } & \multicolumn{3}{|c|}{ Diet } \\
\hline & $\underset{\mathrm{C}-\mathrm{SB}}{\mathrm{A}}$ & $5 \% \stackrel{\mathrm{B}}{\mathrm{MBS}}$ & ${ }_{10 \%}^{\mathrm{C}} \mathrm{MBS}$ \\
\hline $\begin{array}{l}\text { No. pens/diet } \\
\text { No. gilts/pen } \\
\text { Initial wt., kg. } \\
\text { Av, daily gain, kg.a } \\
154 \text {-day wt., kg, } \\
\text { Age at puberty, days b }\end{array}$ & $\begin{array}{c}3 \\
6 \\
19.3 \\
0.65 \\
82.6 \\
237 \quad(232)\end{array}$ & $\begin{array}{c}3 \\
6 \\
19.7 \\
0.65 \\
83.5 \\
233 \quad(224)\end{array}$ & $\begin{array}{c}3 \\
6 \\
19.3 \\
0.61^{*} \\
77.6 \\
225\end{array}$ \\
\hline
\end{tabular}

a Average for a 114-day period following assignment to the experiment.

Includes a missing value calculated for one gilt in replion diet $B$ that died before reaching puberty. One gil on diet $A$ and two gilts on diet $B$ were not observed in heat included as having reached puberty on the day of slaughter. included as having reached puberty on the day of slauges
The averages in parenthesis exclude these three gilts. $* \mathfrak{p}<.05$.

bone scrap diet (C). This observation is similar to that reported by Peo and Hudman (1962).

Examination of the puberty data revealed a tendency for gilts fed the higher level of meat and bone scraps to reach puberty at a younger age. However, the difference is not statistically significant and is primarily the result of one gilt on diet $A$ and two gilts on diet $B$ not cycling by approximately $10 \mathrm{mo}$. of age. The puberal age assigned these gilts (actual slaughter age) was well out of the range observed for all other gilts in the experiment. The average ages at puberty are quite comparable when these gilts are excluded (table 2). It seems unlikely that the diet is the cause of the low incidence of retarded puberty observed.

Because of the important negative relationship that has been reported between weight gain and age at puberty (Warnick et al., 1951; Foote et al., 1956; Zimmerman et al., 1960), the data were further treated to determine if the depressed weight gain produced by diet $\mathrm{C}$ influenced the expression of puberty. Zimmerman et al. (1960) reported that most of the variation in puberal age in response to restricted feeding is indirect, i.e., is accounted for by the variation in weight gain caused by restricted feeding. The association between 154-day weight and age at puberty in this experiment was negligible (within group $\mathrm{r}=-.180, \mathrm{P}>0.1)$. The adjustment of puberal age for variation in 154-day weight did not alter appreciably the small difference originally observed; thus the depression in weight gain is not the reason for the lack of a significant response to animal protein in this study.

These data would appear to be in disagree- ment with the finding of Fowler and Robertson (1954) who reported a significantly younger age at puberty in gilts fed a plant and animal protein diet as compared to an all-plant diet. However, when the all-plant protein diet was fortified with an antibioticvitamin $\mathbf{B}_{12}$ premix, a marked decrease in puberal age was noted; a comparable decrease was not observed on the plant-animal protein diet. The data from the antibiotic and vitamin $\mathrm{B}_{12}$ supplemented gilts correspond more closely to the data obtained in the present experiment where both diets were fortified with antibiotic and vitamin $B_{12}$. It would seem that at least part of the advantage in puberty reported for animal protein sources may be attributable to their higher content of vitamin $\mathbf{B}_{12}$. This would not be a factor in adequately fortified diets.

As shown in table 3, diet did not exert any appreciable effect on ovulation rate or embryo survival. The net result was a similar litter size at slaughter for gilts across all diets. Fowler and Robertson (1954) reported a slight, although not a significant, advantage in litter size ( 0.5 more embryos) at 25 days of gestation in gilts that received half of their supplemental protein from meat and bone scraps in place of soybean meal. The larger litter size resulted from a greater ovulation rate ( 0.9 ova) in the gilts fed meat and bone scraps; embryo survival was unaffected. More recent work by Teague and Rutledge (1960) demonstrated no advantage in ovulation rate or prenatal survival from replacing half of the supplemental plant protein (soybean meal) in an all-plant diet with protein from

TABLE 3. POST-BREEDING REPRODUCTIVE PERFORMANCE AS INFLUENCED BY TWO LEVELS OF MEAT AND BONE SCRAPS

\begin{tabular}{|c|c|c|c|}
\hline \multirow[b]{2}{*}{ Item } & \multicolumn{3}{|c|}{ Diet } \\
\hline & $\begin{array}{c}\text { A } \\
\text { C-SB }\end{array}$ & $\begin{array}{c}\text { B } \\
5 \% \\
\text { MBS }\end{array}$ & $\begin{array}{c}\mathrm{C} \\
10 \% \\
\mathrm{MBS}\end{array}$ \\
\hline \multirow{4}{*}{$\begin{array}{l}\text { No. gilts mated } \\
\text { Ovulation rate, } 2 \text { nd } \\
\text { estrus } \\
\text { Percent embryo sur- } \\
\quad \text { vival, } 26-28 \text { days } \\
\text { No. live embryos/ } \\
\text { gilt mated }\end{array}$} & 16 & 15 & 18 \\
\hline & 14.5 & 14.1 & 14.1 \\
\hline & 66.9 & 70.4 & 66.1 \\
\hline & 9.6 & 9.7 & 9.1 \\
\hline \multicolumn{4}{|c|}{$\begin{array}{l}\text { "Gilts were not mated for the following reasons: one gilt } \\
\text { died, three gilts failed to attain puberty and the mating estrus } \\
\text { was not detected in one gilt. } \\
\text { b Includes one gilt not observed in second heat that ovulated } \\
\text { and had a new crop of corpora lutea at slaughter } 30 \text { days } \\
\text { following the puberal estrus. } \\
\text { c Includes one gilt on each diet that returned to heat before } \\
\text { slaughter; these gilts were included as contributing } 0 \% \text { sur- } \\
\text { vival and } 0 \text { lifter size. }\end{array}$} \\
\hline
\end{tabular}


meat and bone scraps. Further, they failed to find any consistent difference in farrowing and lactation performance when sows and their offspring were fed these diets for three generations. Similarly, Clawson and Barrick (1959) and Mayrose et al. (1964) did not observe any significant difference in litter size at birth when part or all of the supplemental protein of plant origin was replaced with protein of animal origin. In addition, these workers found that gilts and sows fed the all-plant diet weaned significantly heavier pigs than those fed mixed protein diets.

From the results of the present experiment and the published literature, there is little evidence that swine reproduction is enhanced by replacing part or all of the supplemental protein in properly fortified all-plant diets with protein of animal origin.

\section{Summary}

Fifty-four crossbred gilts were fed diets containing 0,5 and $10 \%$ meat and bone scraps (MBS) to determine the value for swine reproduction of replacing part of the supplemental protein in a vitamin-fortified all-plant diet (corn-soybean meal diet with added $B_{12}$ ) with protein of animal origin.

The 0 and $5 \%$ MBS diets supported more rapid gains $(\mathrm{P}<.05)$ during the 16-week gain test than the $10 \%$ MBS diet. No treatment differences were observed, however, for any of the reproductive traits measured; age at puberty, ovulation rate at second estrus, embryo survival and litter size at 26 to 28 days of gestation were not improved by substituting animal protein for part of the supplemental protein of plant origin.

\section{Literature Cited}

Clawson, A. J. and E. R. Barrick. 1959. A comparison of soybean meal and soybean meal plus meat scraps fed in equal parts as supplemental protein for bred gilts. N.C.A.I. Rpt. 59, A. H. Series 57.

Foote, W. C., D. P. Waldorf, A. B. Chapman, H. L. Self, R. H. Grummer and L. E. Casida. 1956. Age at puberty of gilts produced by different systems of mating. J. Animal Sci. 15:959.

Fowler, S. H. and G. L. Robertson. 1954. Some effects of source of protein and an antibiotic on reproductive performance in the gilt. J. Animal Sci. 13:949.

Mayrose, V. B., V. C. Speer, V. W. Hays and J. T. McCall. 1964. Effect of an antibiotic (Tylosin) and protein source on swine reproduction. J. Animal Sci. 23:737.

Moustgaard, J. 1952. The importance of cyanocobalmin for fertility in sows and gilts. Proc. VIth Int Cong. Animal Husbandry, Sect. 3, p. 71.

Nutrient Requirements of Swine. 1959. National Academy of Sciences, National Research Council Publ. 648, p. 9.

Peo, E. R., Jr. and D. B. Hudman. 1962. Effect of levels of meat and bone scraps on growth rate and feed efficiency of growing-finishing swine. J. Animal Sci. 21:787.

Teague, H. S. and E. A. Rutledge. 1960. Soybean oil meal as a protein source for successive generations of swine. J. Animal Sci. 19:902.

Warnick, A. C., F. L. Wiggins, L. E. Casida, R. H. Grummer and A. B. Chapman. 1951. Variation in puberty phenomena in inbred gilts. J. Animal Sci. 10:479.

Zimmerman, D. R., H. G. Spies, E. M. Rigor, H. L. Self and L. E. Casida. 1960. Effect of restricted feeding, crossbreeding and season of birth on age at puberty in swine. J. Animal Sci. 19:687. 